\title{
Magnetophoretic Behavior of 3T3 Cells Incubated with Saccharide-Coated MNPs
}

DOI:

10.1557/adv.2016.648

\section{Document Version}

Accepted author manuscript

Link to publication record in Manchester Research Explorer

\section{Citation for published version (APA):}

Fallows, T., Coxon, T., Gough, J., \& Webb, S. (2017). Magnetophoretic Behavior of 3T3 Cells Incubated with Saccharide-Coated MNPs. MRS Advances, 2(24). https://doi.org/10.1557/adv.2016.648

\section{Published in:}

MRS Advances

\section{Citing this paper}

Please note that where the full-text provided on Manchester Research Explorer is the Author Accepted Manuscript or Proof version this may differ from the final Published version. If citing, it is advised that you check and use the publisher's definitive version.

\section{General rights}

Copyright and moral rights for the publications made accessible in the Research Explorer are retained by the authors and/or other copyright owners and it is a condition of accessing publications that users recognise and abide by the legal requirements associated with these rights.

\section{Takedown policy}

If you believe that this document breaches copyright please refer to the University of Manchester's Takedown Procedures [http://man.ac.uk/04Y6Bo] or contact uml.scholarlycommunications@manchester.ac.uk providing relevant details, so we can investigate your claim.

\section{OPEN ACCESS}




\title{
Magnetophoretic Behavior of 3T3 Cells Incubated with Saccharide-Coated MNPs
}

\author{
Thomas W. Fallows ${ }^{\dagger, 1,2}$ Thomas P. Coxon ${ }^{\dagger, 1,2}$ Julie E. Gough ${ }^{2}$ and Simon J. Webb ${ }^{1}$ \\ ${ }^{1}$ School of Chemistry and Manchester Institute of Biotechnology, University of Manchester, 131 \\ Princess Street, Manchester, M1 7DN, UK \\ ${ }^{2}$ School of Materials, University of Manchester, MSS Tower, Manchester, M13 9PL, UK \\ These authors contributed equally to this work.
}

\begin{abstract}
Providing magnetite nanoparticles with saccharide coatings has been found to significantly increase the interactions of the nanoparticles with cells. Glucose (Glc) or $N$ acetylglucosamine (GlcNAc) coated magnetic nanoparticles (MNPs) were used to magnetically label 3T3 fibroblast cells, and the response of the labelled cells to external magnetic fields was studied. It was found that cells incubated with Glc- or GlcNAc-coated nanoparticles were much more likely to move towards an external magnet than those incubated with uncoated nanoparticles. Furthermore, cells in suspension moved much faster than those in contact with the surface of polystyrene well plates, with stronger magnets increasing the speed of movement. Cells that were adhering to the floor of the cell culture well and did not move in the $x-y$ plane could still be rotated about the z-axis by moving the external magnet around the cell.
\end{abstract}

\section{INTRODUCTION}

Magnetite nanoparticles are used in a wide variety of biomedical applications, ${ }^{1,2}$ so understanding cell-MNP interactions is of keen interest. Externally added MNPs are often taken up by cells in vitro and in vivo, resulting in magnetic labelling of those cells. This labelling allows for the manipulation of the cells via magnetophoresis, ${ }^{3}$ whereby the cells move when placed in an external magnetic field.

There are many biomedical applications for magnetophoresis, for example, external control over the location of nanoparticles in vivo for therapeutic and diagnostic purposes, ${ }^{4}$ the removal of specific cell lines suspended in blood ${ }^{5}$ and separation of cell lines for screening and research. ${ }^{6,7}$ In order to improve MNP-mediated magnetophoresis of cells, the nanoparticles should be coated with a biocompatible agent to improve adhesion to and uptake by the target cells. Common reagents for coating magnetic nanoparticles include dextran, ${ }^{8} 3$-aminopropyltriethoxysilane $(\text { APTES })^{9}$ and polyethylene glycol (PEG),${ }^{10}$ but none of these molecules are able to target specific cell types through specific interactions. In contrast, saccharide-coated nanoparticles are able to exploit cells' natural recognition pathways by binding to cell-surface lectins, taking advantage of the strong and specific binding produced by the multiple individual binding events, ${ }^{11-13}$ known as the cluster glycoside effect. ${ }^{14}$ Since catechols ${ }^{15}$ and resorcinols ${ }^{16}$ are known to bind to the surface of $\mathrm{Fe}_{3} \mathrm{O}_{4}$ nanoparticles, these functional groups were chosen to anchor the cell targeting saccharides to the MNPs. Saccharide-terminated coating molecules have previously been synthesized by reacting a catechol or resorcinol hydrazide with a reducing sugar to give adducts that can coat magnetite nanoparticles, with the coated MNPs shown to interact with cells. ${ }^{17}$ However the magnetophoretic response of these labelled cells to static magnetic fields of different strengths and changing orientations was unexpored, as was the effect of changing the saccharide coating anchor (catechol or resorcinol) on magnetic responsiveness. 


\section{EXPERIMENTAL PROCEDURES}

\section{General materials:}

Reagents were purchased from Sigma-Aldrich Co. Ltd., Dorset, UK with the exception of 3,4dihydroxybenzhydrazide which was purchased from Alfa Aesar, Lancashire, UK and

Fluorochem, Derbyshire, UK. Magnetite nanoparticles (nanopowder, $<50 \mathrm{~nm}$ (TEM), $\geq 98 \%$ trace metals basis) were purchased from Sigma-Aldrich Co. Ltd., Dorset, UK. Magnets were purchased from e-magnets UK, Hertfordshire, UK. The saccharide conjugates 1, 2, 3 and $\mathbf{4}$ were synthesized and characterized as per literature procedures. ${ }^{17}$ For cell experiments DMEM refers to Dulbecco's Modified Eagle Media with added fetal bovine serum $(10 \% \mathrm{v} / \mathrm{v})$ and antibiotics (1 $\% \mathrm{v} / \mathrm{v}$ penicillin and streptomycin).

\section{Equipment:}

Nanoparticle sonication was performed at $20 \mathrm{kHz}$ using a Sonics VCX130PB Ultrasonic processor with a stepped micro tip (3 mm diameter, $136 \mathrm{~mm}$ length). Bright field microscope images were taken using a Leica DM IL microscope equipped with a SPOT Insight Color 3.2.0 camera. Where necessary, cell counting analysis was carried out using ImageJ.

\section{General nanoparticle coating procedure:}

Magnetite nanoparticles $(10 \mathrm{mg})$ were suspended in methanol $(5 \mathrm{~mL})$ by probe sonication for 5 minutes. To this suspension was added the desired coating molecule, $\mathbf{X}(0.1 \mathrm{mmol})$. The sample was sonicated for a further 45 minutes to give $\mathbf{X}$-MNP. The coated MNPs were purified by centrifugation, supernatant removal and methanol washing $(3 \times 10 \mathrm{~mL})$. Finally, the coated nanoparticles were resuspended in milli-Q filtered water $(1 \mathrm{~mL})$ and used immediately.

\section{Cell culture:}

3 T3 cells were cultured in $25 \mathrm{~mL}$ culture flasks using DMEM. The culture flasks containing the cells were incubated at $37{ }^{\circ} \mathrm{C}$ in an atmosphere of $5 \%$ carbon dioxide. Cells were cultured once they reached confluence, using trypsin $(1 \mathrm{~mL})$ to detach the cells from the culture flask. They were separated into new flasks at a dilution of 1 in 8 .

\section{Cell microscopy:}

$3 \mathrm{~T} 3$ cells were incubated in $25 \mathrm{~mL}$ culture flasks for $24 \mathrm{~h}$ at $37{ }^{\circ} \mathrm{C}$ in a $5 \%$ carbon dioxide atmosphere. Nanoparticles suspended in milli-Q filtered water were added to the flasks to give a concentration of $0.1 \mathrm{mg} / \mathrm{mL}$, then the cells incubated for a further $24 \mathrm{~h}$. The DMEM was removed and flask washed with phosphate buffered saline (PBS) $(3 \times 10 \mathrm{~mL})$ to remove unattached MNPs. The cells were detached from the flask using trypsin $(1 \mathrm{~mL})$ and diluted in DMEM to 16,000 cells $/ \mathrm{mL}$ before seeding into a 24 well plate $(1 \mathrm{~mL} /$ well $)$ with a magnet $(0.29$ T, cylindrical N42 magnet, $3 \mathrm{~mm} \times 12 \mathrm{~mm}$ or $0.36 \mathrm{~T}$, counter sunk square N42 magnet, $10 \mathrm{~mm}$ x $5 \mathrm{~mm}, 4 \mathrm{~mm}$ hole) beneath and to one side of the well. To measure speed of cell movement, cells were imaged immediately and then at intervals of $5 \mathrm{~s}$. For near/far experiments, cells were incubated for 10 mins before imaging.

\section{DISCUSSION}

In order to determine the effect of different coatings on the uptake and resultant magnetic responsiveness of cells, 3T3 cells were incubated with samples of commercial nanoparticles $(0.1$ $\mathrm{mg} / \mathrm{mL}$ ), each coated with different saccharide conjugates; Glc- and GlcNAc-terminated resorcinol conjugates ( $\mathbf{1}$ and $\mathbf{2}$ ) and analogous catechol conjugates ( $\mathbf{3}$ and $\mathbf{4}$ ) (Figure 1a). A sample of nanoparticles with no added coating was also used ("uncoated" MNPs). In addition, a 
control experiment was performed with no nanoparticles. In each case, the appropriate nanoparticle sample was then added to 3 T3 cells to give a total concentration of $0.1 \mathrm{mg} / \mathrm{mL}$ and incubated for $24 \mathrm{~h}$. Loose nanoparticles were washed away with PBS buffer $(3 \times 10 \mathrm{~mL})$ and cells were detached from the flask using trypsin $(1 \mathrm{~mL})$. The cells were resuspended in DMEM, diluted to 16,000 cells $/ \mathrm{mL}$ and transferred to a 24 well plate $(1 \mathrm{~mL} /$ well $)$. A permanent magnet was immediately placed below and to one side of the well (Figure $1 \mathrm{~b}$ ).

a)<smiles>O=C(NNC1O[C@H](CO)C(O)[C@H](O)C1O)c1cc(O)cc(O)c1</smiles><smiles>O=C(NNC1O[C@H](CO)C(O)[C@H](O)[C@H]1O)c1ccc(O)c(O)c1</smiles><smiles>O=N[C@H]1C(NNC(=O)c2cc(O)cc(O)c2)O[C@H](CO)C(O)C1O</smiles>

b)

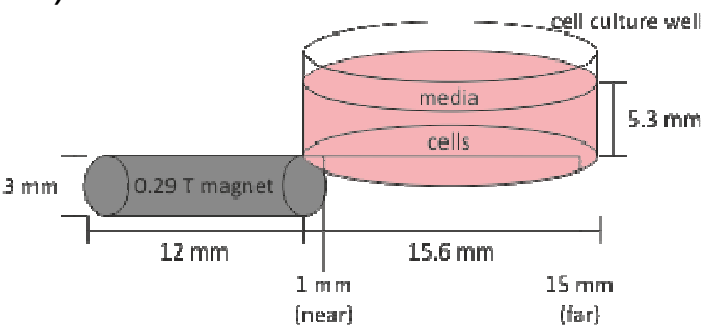

4

Figure 1: a) Structure of coating reagents Glc-res 1, GlcNAc-res 2, Glc-cat 3 and GlcNAc-cat 4. b) Cartoon representation of the location of the magnet next to the well plate and the distance at which images were taken (not to scale).

Cells with bound or internalized nanoparticles started to move towards the magnet. To qualitatively assess cell magnetophoresis, microscopy images were taken close to $(1 \mathrm{~mm})$ and far from $(15 \mathrm{~mm})$ the magnet. These images were taken after 10 minutes, when most cell movement had ceased but the cells had not yet begun to spread and so could be counted easily. The number of cells within the $750 \times 750 \mu \mathrm{m}$ area of each image was counted for each sample (Table I). Each assay was carried out a minimum of three and a maximum of twelve times.

\begin{tabular}{|c|c|c|c|c|}
\hline \multirow{2}{*}{ Sample } & \multicolumn{2}{|c|}{ Mean No. of Cells (after 10 mins) $^{\ddagger}$} & \multirow{2}{*}{ Near/Far } & $\begin{array}{c}\text { \% increase in cells } \\
\text { near to magnet }^{\#}\end{array}$ \\
\cline { 2 - 3 } No MNPs & Near & Far & 1.2 & 7 \\
Uncoated MNPs & 145.0 & 125.4 & 2.1 & 36 \\
1-MNP & 272.1 & 130.1 & 9.4 & 81 \\
2-MNP & 640.3 & 68.3 & 10.9 & 82 \\
3-MNP & 734.4 & 67.7 & 3.2 & 52 \\
4-MNP & 75.6 & 23.8 & 9.9 & 82 \\
\hline
\end{tabular}

Table I: Ratio of cells incubated with coated and uncoated magnetite nanoparticles near and far from an external magnetic field. Standard errors in cell counts estimated to be $10 \%$.

${ }^{\ddagger}$ Number of cells averaged over a minimum of three and maximum of twelve experiments.

${ }^{\#}[($ near - far $) /($ near + far $) \times 100]$.

In most cases, a greater number of cells were seen close to the magnet (Figure 2) and this effect was considerably more pronounced when saccharide-coated nanoparticles were used. However, there was found to be little difference between the response of cells incubated with glucose-coated nanoparticles and those incubated with GlcNAc-coated nanoparticles, consistent with reports that $3 \mathrm{~T} 3$ cells express both glucose- and GlcNAc-binding proteins on their surface. ${ }^{18}$ 
The uncoated nanoparticles were taken up to some extent, although these bare nanoparticles are unlikely to remain uncoated upon addition to DMEM, with adsorption of solutes in the DMEM giving coatings that may facilitate cellular recognition.

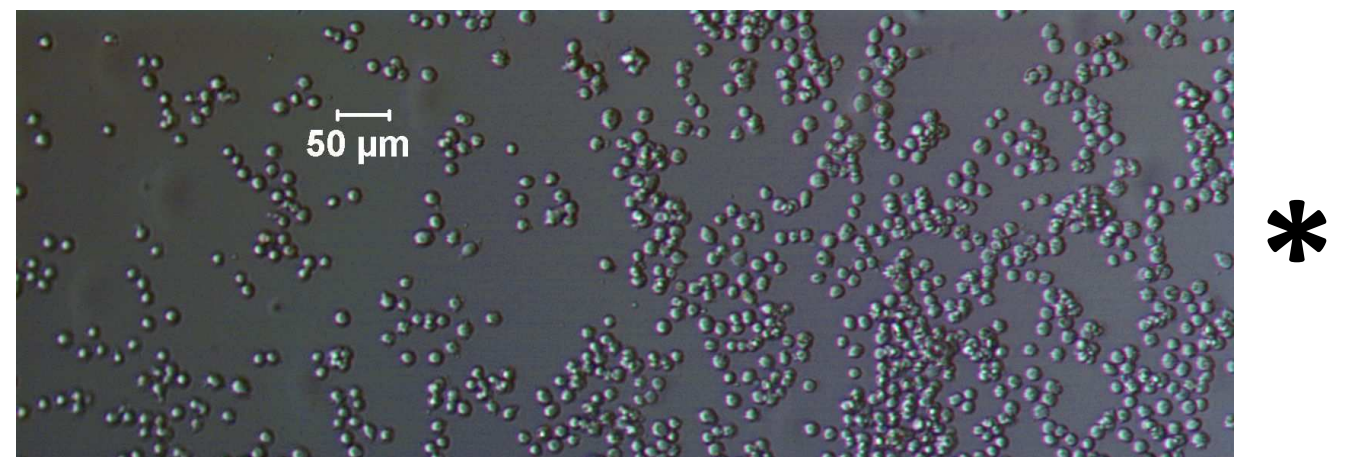

Figure 2: Microscopy image of 3T3 cells incubated with 2-MNPs in a cell culture well after 10 minutes' incubation with an external 0.29 T magnet. Magnet location indicated by asterisk.

Further investigations were carried out to quantify the magnetophoresis of these magnetically labelled cells. Following previous protocols, 3T3 cells were incubated with 2 and 4 coated MNPs $(0.1 \mathrm{mg} / \mathrm{mL})$. After transferring the cells to a well plate, with the cells still in suspension, a static magnetic field ( $0.29 \mathrm{~T}$, cylindrical magnet) was applied and the suspension imaged imtely by bright field microscopy. The cells in suspension were observed to move towards the magnet but those cells that came into contact with the floor of the well plate slowed to a stop within 30 seconds. Cell movement was observed for around 40-50 minutes in total, after which time all cells had settled on to the floor of the well plate and had begun to attach to the surface. By measuring the distance travelled by a given cell over the first 40 minutes, it was possible to calculate the average speed at which the cells moved towards the magnet (Figure 3).

a)

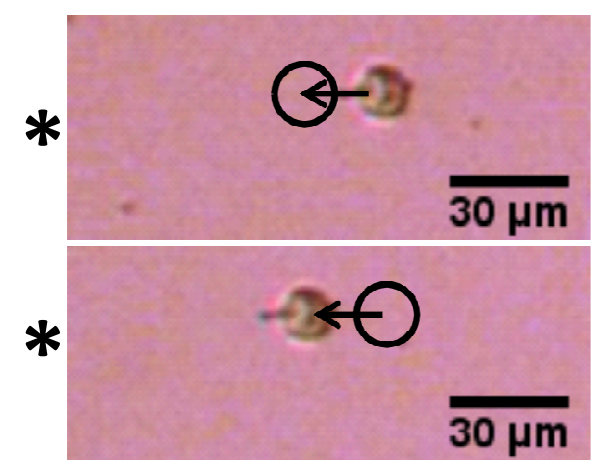

b)

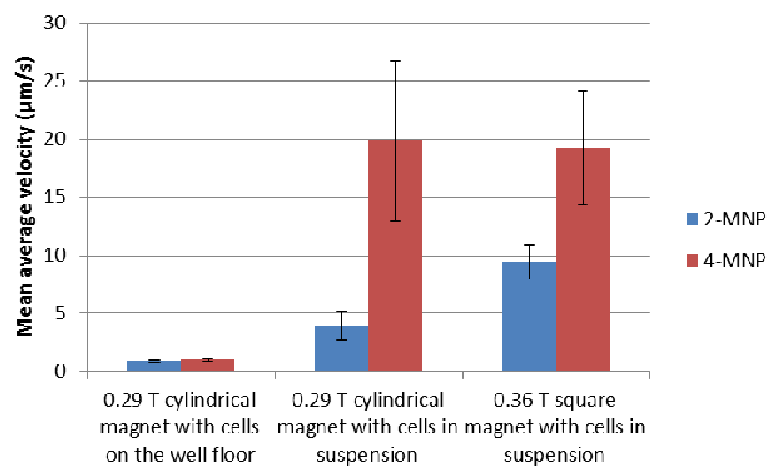

Figure 3: a) Illustrative example of cells incubated with 4-MNP moving towards an external magnet. Images were taken in the same location $10 \mathrm{~s}$ apart. Magnet location indicated by asterisk. b) Graph showing speed of cells incubated with 2-MNP (blue bars) and 4-MNP (red bars) in different locations and with different magnet strengths.

This analysis showed that contact with the well surface reduces cell velocity by $75 \%$ to $95 \%$, and that MNPs with catechol coatings produced cells that were more responsive to the external magnetic field. Using a stronger (0.36 T, $10 \mathrm{~mm}$ square) magnet gave an impressive $140 \%$ 
increase in speed for cells labelled by 2-MNP, but little difference for the more responsive 4MNP labelled cells. All values obtained ( 4 to $19 \mu \mathrm{m} / \mathrm{s}$ ) were considerably smaller that the $49 \pm 9$ $\mu \mathrm{m} / \mathrm{s}$ range reported by Bertorelle et al., ${ }^{19}$ who used a much stronger $(1.48 \mathrm{~T})$ magnet.

Experiments were also carried out to observe the response of cells associated with 2MNP to static magnetic fields applied in successively different orientations. The magnetic field was applied only after washing away and loose nanoparticles with PBS buffer, but prior to any other procedure. Upon application of a magnet at a distance of $1 \mathrm{~mm}$ from cells that had settled and attached, it was observed that nanoparticles within the cell aligned themselves with the magnetic field lines. These MNPs gave the cells a punctate appearance, consistent with the MNPs in organelles such as endosomes. There are a number of possible explanations for this behavior, though previous reports ${ }^{19}$ suggest that restricted internal movement may be due to the particles residing within endosomes.

The effect of changing magnet orientation on the behavior of adhering magneticallylabelled cells was then assessed. A magnet was placed $20 \mathrm{~mm}$ from the well and its position relative to the sample was altered. The attached cells rotated to align themselves with the changing orientation of the magnetic field (Figure 4). The mechanism by which attached cells detach and the either move or rotate in response to an external magnetic field orientation is unclear, but could be due to the progressive removal and attachment of actin filaments to the polystyrene well plate. ${ }^{20}$
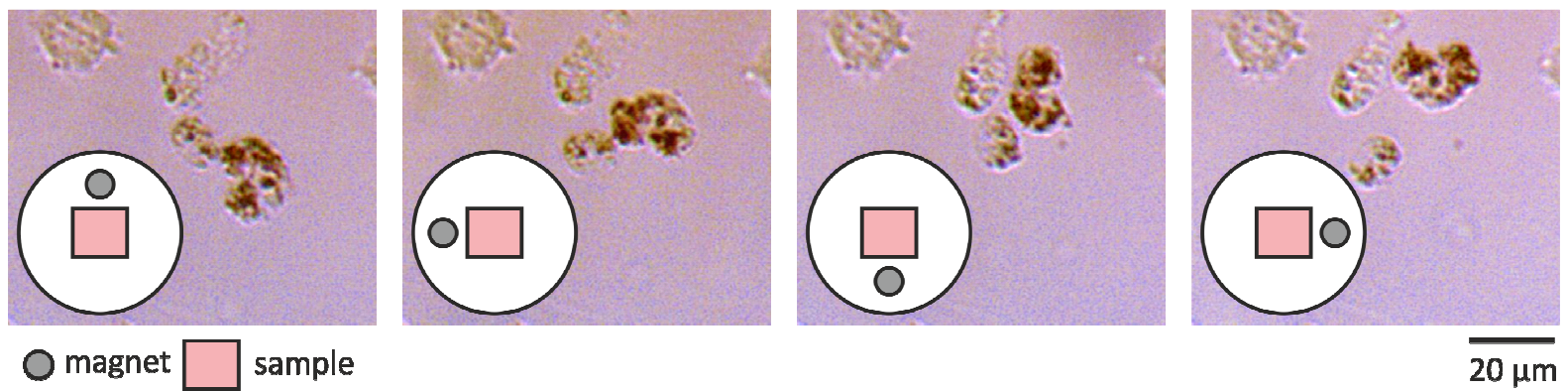

Figure 4: Optical microscopy images showing magnetically induced rotation of magneticallylabelled 3T3 cells (2-coated magnetic nanoparticles visible as dark spots) around the z-axis.

\section{CONCLUSIONS}

Glc- and GlcNAc- coatings on magnetic nanoparticles were found to increase MNP interactions with cells and make the cells more responsive to static external magnetic fields, which we suggest is due to increased MNP endocytosis by the cells. Qualitative assays suggested little difference in magnetic patterning resulted if either resorcinol or catechol links attached the saccharides to the $\mathrm{Fe}_{3} \mathrm{O}_{4}$ MNP surfaces, despite the lower stability of the former link. ${ }^{17} \mathrm{We}$ suggest that this observation is consistent with MNP endocytosis, after which the coating on internalized MNPs does not determine cellular magnetic responsiveness. Cells in suspension can move at speeds of up to $19 \mu \mathrm{m} / \mathrm{s}$, however once cells adhere to a surface this drops dramatically to approximately $1 \mu \mathrm{m} / \mathrm{s}$. Controlled magnetophoresis could find applications in manipulating cells that are free-floating in the bloodstream, such as metastatic cancer cells or bacterial cells in sepsis patients. Internalized MNPs do not move within cells in response to an external magnetic 
field but MNP-labelled organelles, such as endosomes, appear to align along the field lines. Entire cells will also reorient themselves to match the direction of the applied magnetic field.

\section{ACKNOWLEDGMENTS}

TWF, TPC and SJW would like to thank the North-West Nanoscience Doctoral Training Centre, EPSRC grants EP/K039547/1, EP/G03737X/1 and EP/N009134/1 for funding. We would also like to thank Dr. Louise Carney for assistance with cell culture.

\section{REFERENCES}

1. A.K. Gupta and M. Gupta, Biomaterials 26, 3995 (2005).

2. S. Laurent, D. Forge, M. Port, A. Roch, C. Robic, L.V. Elst and R.N. Muller, Chem. Rev. 108, 2064 (2008).

3. N. Pamme and A. Manz, Anal. Chem. 76, 7250 (2004).

4. N. Schleich, C. Po, D. Jacobs, B. Ucakar, B. Gallez, F. Danhier and V. Préat, J. Control. Release 194, 82 (2014).

5. J.H. Kang, M. Super, C.W. Yung, R.M. Cooper, K. Domansky, A.R. Graveline, T. Mammoto, J.B. Berthet, H. Tobin, M.J. Cartwright, A.L. Watters, M. Rottman, A. Waterhouse, A. Mammoto, N. Gamini, M.J. Rodas, A. Kole, A. Jiang, T.M. Valentin, A. Diaz, K. Takahashi and D.E. Ingber, Nat. Med. 20, 1211 (2014).

6. $\quad$ N. Pamme, J.C.T. Eijkel and A. Manz, J. Magn. Magn. Mater. 307, 237 (2006).

7. C. Carr, M. Espy, P. Nath, S.L. Martin, M.D. Ward and J. Martin, J. Magn. Magn. Mater. 321, 1440 (2009).

8. C.C. Berry, S. Wells, S. Charles and A.S.G. Curtis, Biomaterials 24, 4551 (2003).

9. F. Galeotti, F. Bertini, G. Scavia and A. Bolognesi, J. Colloid Interface Sci. 360, 540 (2011).

10. E.K.U. Larsen, T. Nielsen, T. Wittenborn, H. Birkedal, T. Vorup-Jensen, M.H. Jakobsen, L. Østergaard, M.R. Horsman, F. Besenbacher, K.A. Howard and J. Kjems, ACS Nano 3, 1947 (2009).

11. C. Tassa, J.L. Duffner, T.A. Lewis, R. Weissleder, S.L. Schreiber, A.N. Koehler and S.Y. Shaw, Bioconjugate Chem. 21, 14 (2010).

12. M. Marradi, M. Martín-Lomas and S. Penadés, Adv. Carbohydr. Chem. Biochem. 64, 211 (2010).

13. G.T. Noble, S.L. Flitsch, K.P. Liem and S.J. Webb, Org. Biomol. Chem. 7, 5245 (2009).

14. J.J. Lundquist and E.J. Toone, Chem. Rev. 102, 555 (2002).

15. T. Coxon, A. Almond, J.E. Gough and S.J. Webb, MRS Proc. 1688, doi: 10.1557/opl.2014.433 (2014).

16. G. Absalan, M. Asadi, S. Kamran, L. Sheikhian and D.M. Goltz, J. Hazard. Mater. 192, 476 (2011).

17. T.P. Coxon, T.W. Fallows, J.E. Gough and S.J. Webb, Org. Biomol. Chem. 13, 10751 (2015).

18. S.A. Harrison, J.M. Buxton and M.P. Czech, Proc. Natl. Acad. Sci. USA 88, 7839 (1991).

19. F. Bertorelle, C. Wilhelm, J. Roger, F. Gazeau, C. Ménager and V. Cabuil, Langmuir. 22, 5385 (2006).

20. T.D. Pollard and G.G. Borisy, Cell 112, 453 (2003). 